\title{
Onychomadesis in children: think about a late complication of hand-foot-mouth disease
}

\section{Anissa Zaouak, Leila Bouhajja, Houda Hammami, Samy Fenniche}

\author{
Department of Dermatology, Habib Thameur Hospital, Tunis, Tunisia
}

Corresponding author: Dr. Anissa Zaouak, E-mail: anissa_zaouak@yahoo.fr

\begin{abstract}
Hand foot mouth disease (HFMD) is considered to be the most common infectious disease in association with onychomadesis. Coxsackie A6 may be the major subtype associated with onychomadesis after HFMD. A 2-yearold female child was referred to our department for an acute vesiculobullous eruption since two days with fever. Dermatological examination revealed a vesiculobullous eruption located on her hands and on her feet. Two months later she consulted for changes of her finger nails which appeared since 3 weeks. Her parents denied a nail trauma or fungal infection. The diagnosis of onychomadesis secondary to this HFMD was diagnosed. Physical examination revealed nail matrix arrest on her right index and right middle finger. The nail changes healed spontaneously without medication within two months. Practioners should be aware of this late complication to avoid unnecessary treatments and to recommend a simple follow-up.
\end{abstract}

Key words: Neonatal onychomadesis; Hand-foot-mouth disease; Onychomadesis

\section{INTRODUCTION}

Hand-foot-mouth disease (HFMD) is an acute infection caused most often by coxsackie A virus type 6 and enterovirus 71 frequently in children [1]. It generally starts with oral lesions after 4-6 days of incubation period [2].

\section{CASE REPORT}

A 2-year-old female child was referred to our department for an acute vesiculobullous eruption since two days with fever. Dermatological examination revealed a vesiculobullous eruption located on her hands (Fig. 1) and on her feet (Fig. 2). She also had some superficial erosions on her mouth. The diagnosis of hand-footmouth disease was assessed. She healed spontaneously within 4 days. Two months later she consulted for changes of her finger nails which appeared since 3 weeks. Her parents denied a nail trauma or fungal infection. On further quiery and since she suffered from hand-foot-mouth disease since two months, the diagnosis of onychomadesis secondary to this syndrome was diagnosed. Physical examination revealed nail matrix arrest on her right index and right middle finger (Fig. 3). The nail changes healed spontaneously without medication within two months.

\section{DISCUSSION}

HFMD is characterized by maculopapular and vesicular lesions especially on the hands, feet and mouth. Onychomadesis is the spontaneous separation of the nail plate from the matrix [1]. There are many etiologies responsible of the diagnosis of onychomadesis especially infections such as HFMD especially in children and attributable to coxsackie virus type A6. The first case was reported in 2000 in Chicago [3]. HFMD is considered to be the most common infectious disease in association with onychomadesis. Coxsackie A6 may be the major subtype associated with onychomadesis after HFMD. The nail changes vary from beau's lines to complete nail shedding. The median latency period between HFMD and onychomadesis is 40 days.

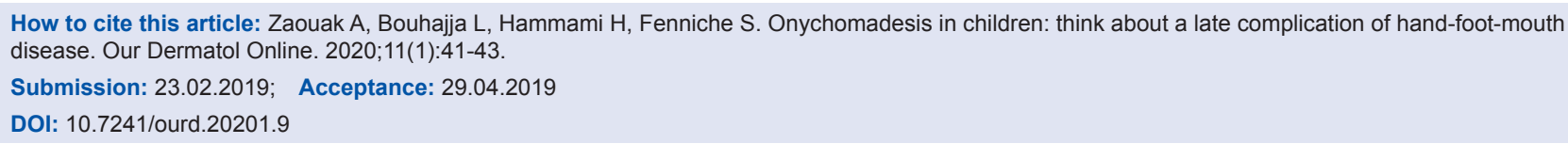




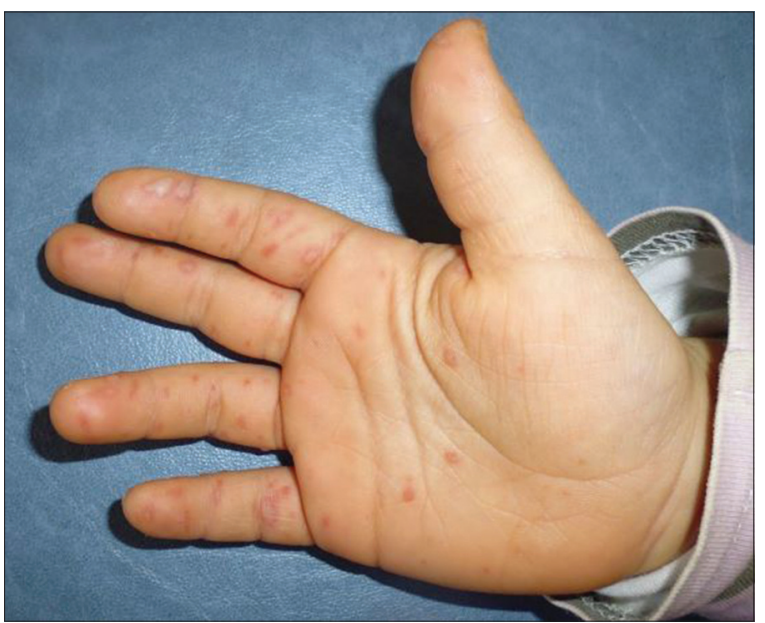

Figure 1: Vesiculobullous eruption on the right hand.

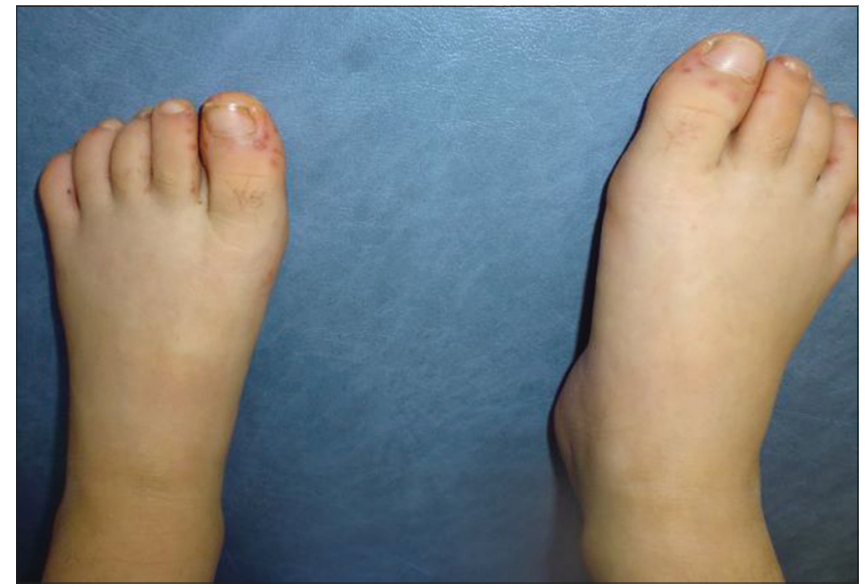

Figure 2: Vesiculobullous eruption on the feet.

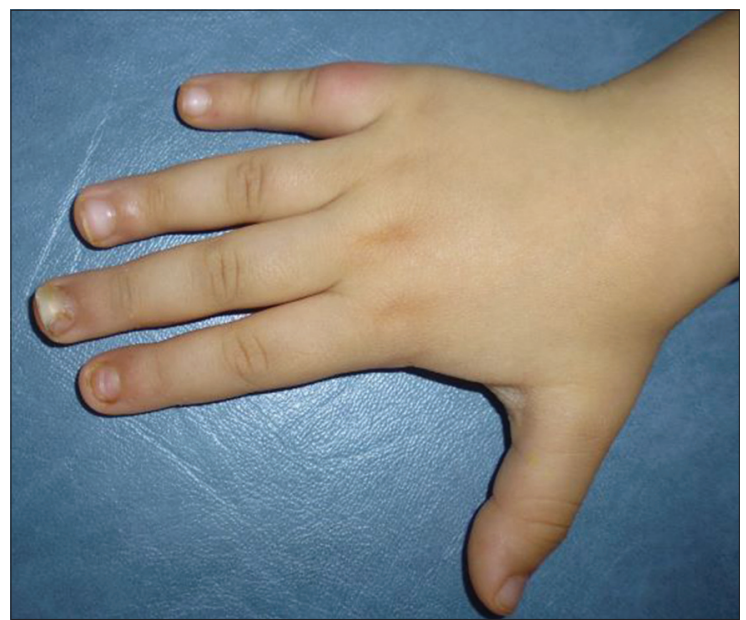

Figure 3: Onychomadesis on the nails of index and middle fingers of right hand.

A study from Taiwan reported that the incidence of onychomadesis in children with hand-foot-mouth disease was $5 \%[4,5]$. This complication is considered even epidemic in Taiwan [2,6]. The mechanism of onychomadesis is still unknown. The difference in the turnover time between skin and nail could explain the delayed onset of nail changes after resolution of the systemic and cutaneous signs of HFMD [7]. Onychomadesis occurring after HFMD is temporary with spontaneous normal regrowth $[8,9]$. Indeed, there is no need for treatment and usually onychomadesis in those children diseappears spontaneously within 1 to 2 months [10].

\section{CONCLUSION}

In front of onychomadesis diagnosis in a child, a history of viral illness especially HFMD should be searched actively [11]. The diagnosis should be suspected especially in a well-appearing patient, absence of a known trauma. We should reassure the patient and his parents that it has a good prognosis and will heal spontaneously within one to two months [12]. Practioners should be aware of this late complication to avoid unnecessary treatments and to recommend a simple follow-up [13].

\section{Consent}

The examination of the patient was conducted according to the Declaration of Helsinki principles.

\section{REFERENCES}

1. Yüksel S, Evrengül H, Özhan B, Yüksel G. onychomadesis - a late complication of hand-foot-mouth disease. J Pediatr. 2016;174:274.

2. Chiu HH, Wu CS, Lan CE. Onychomadesis: A late complication of hand, foot, and mouth disease. J Emerg Med. 2017;52:243-5.

3. Clementz GC, Mancini AJ. Nail matrix arrest following handfoot-mouth disease: a report of five children. Pediatr Dermatol 2000;17:7-11.

4. Akbaş A, Kılınç F, Yakut HI, Metin A. Nail disorders in children, a clinical study. Our Dermatol Online. 2016;7:149-54.

5. Shikuma E, Endo Y, Fujisawa A, Tanioka M, Miyachi Y. Onychomadesis developed only on the nails having cutaneous lesions of severe hand-foot-mouth disease. Case Rep Dermatol Med. 2011;2011:324193.

6. Chiu HH, Lan CC, Wu CS, Kuo KC, Chen GS, Wei KC. Onychomadesis following hand-foot-and-mouth disease. Cutis. 2016;97:E20-1

7. Long DL, Zhu SY, Li CZ, Chen CY, Du WT, Wang X. Late-Onset nail changes associated with hand, foot, and mouth disease: a clinical analysis of 56 cases. Pediatr Dermatol. 2016;33:424-8.

8. Chiriac A, Birsan C, Chiriac AE, Pinteala T, Foia L. Hand, Foot and Mouth disease in northeastern part of Romania in 2012. Our Dermatol Online. 2013;4:226-9.

9. Wei SH, Hang YP, Liu MC. An outbreak of coxsackie virus A6 hand foot and mouth disease associated with onycomadesis in Taiwan. BMC Infect Dis. 2011;14:346.

10. Hardin J, Haber RM. Onychomadesis: literature review. Br J Dermatol. 2015;172:592-6.

11. Dobrev H, Hristova R. A case of onychomadesis following hand, 
www.odermatol.com

foot, and mouth disease. Our Dermatol Online. 2016;7:101-2.

12. Kuehnel NA, Thach S, Thomas DG. Onychomadesis as a late complication of hand-foot-mouth disease: a case series shedding light on nail shedding. Pediatr Emerg Care. 2017;33:e122-3.

13. Akpolat ND, Karaca N. Nail changes secondary to hand-footmouth disease. Turk J Pediatr. 2016;58:287-90.
Copyright by Anissa Zaouak, et al. This is an open-access article distributed under the terms of the Creative Commons Attribution License, which permits unrestricted use, distribution, and reproduction in any medium, provided the original author and source are credited.

Source of Support: Nil, Conflict of Interest: None declared. 